\title{
On the Mucilage Glands of Undaria.
}

\author{
BY \\ K. YENDO, \\ Professor of Botany in the Tohoku Imperial University, Sapporo, Japan.
}

\section{With Plate XLVIII.}

T $\mathrm{N}$ describing Undariopsis (Laminaria) Peterseniana, Miy. et Okam., 1 Dr. Okamura ${ }^{1}$ has noted a peculiar structure in the subepidermal layers of the lamina. As the original paper seems to have but a narrow circulation, it will be desirable to quote here the lines which relate to the subject :-

'Over both the surfaces of the lamina, both younger and older, minute dark dots are thickly scattered, which are easily visible to the naked eye. In a cross section of the lamina we find beneath the cortical layer a roundish-triangular or depressed-conical, deep reddish brown mass enclosed in a hyaline bag, situated beneath a minute hole left in the epidermal layer. On the surface-view of the lamina, epidermal cells appear to converge towards the hole. The chemical nature of these masses I did not study. It may perhaps be an excretion. I mention this here especially, for the presence of dots in this species is so characteristic that it is sufficient in itself to distinguish the species from all others.'

A similar body has been found by Prof. Miyabe in Undaria pinnatifida, Sur., and its variety distans, Miy. et Okam., and by the present writer in Hirome undarioides, Yendo. I have compared the 'dots' of these species and made it clear that they have similar characters in various respects, however much the species may differ. It is very probable that the problematic bodies found in the three genera may be identical in their properties, functions, and mode of formation. But the material studied was all from dried specimens, and, as regards the nature and function of the 'dots', nothing could have been added to the discoverer's remarks. A stay of two weeks at the Oshoro Marine Station in December last

1 Okamura: Enumeration of Algae of Japan (in Japanese), p. I28. I902. (Diagnosis of the genus not yet published). Ibid.: On Laminariaceae of Japan. Bot. Mag. Tokyo, vol. x, p. 99. 1896. Yendo: Three New Algae from Japan. Ibid. : vol. xvii, p. I02. I903.

[Annals of Botany, Vol. XXIII. No. XCII. October, I909.] 
gave me a favourable opportunity to observe the problematic structure on fresh specimens of Undaria pinnatifida, Sur., var. distans, Miy. et Okam. The material was fixed in picric acid as well as in sublimate solution, both saturated in filtered sea-water. It was brought back to the laboratory of the Agricultural College of Sapporo, and further examination has been carried on under various methods of treatment. I have arrived at the conclusion that the 'hyaline body' cannot be anything but a mucilage gland. As such a gland has never been known to occur in other members of the Laminariaceae, and as the species concerned are all confined to Japan, the results obtained in the present study, incomplete as they are, may not be unworthy of publication.

The glands found in the species under consideration vary in their size and shape according to their stage of development and position in a pinnule. At an early stage they are ovate, with the sharper end towards the surface of the frond. They grow gradually into roundish, pyramidal or conical bodies, and may often elongate horizontally through the medullary tissue. Details of their development will be given afterwards.

In the fresh specimens the substance contained in a mucilage gland is a colourless and highly refractive mass. In the material preserved in alcohol, after being fixed in the picric acid solution directly from the fresh specimens, the contents are also colourless. Okamura does not mention whether the specimens he studied had been preserved by any method of treatment, or were fresh ones. But in the dried specimens or in those preserved in formalin, or in those preserved in alcohol after being fixed in the sublimate solution, the contents are always brown as has been described by him. In the older parts which are nearly going to decay, in the formalin specimens, the contents become of a dark brownish colour approaching almost to black. As a 'minute hole' is situated just above each gland, a fresh frond in surface view shows numerous colourless spots, instead of the dark brownish dots, scattered in the brown epidermal layer. These spots are irregularly distributed all over the blade, but very few, if any, in the stem and rachis. I could not detect any in the rhizines and sporophylls.

The number of glands in a blade varies considerably according to the part and to the age of the plant, as well as to the individual. In general, however, it may be safely remarked that they are proportionally most rich in the young pinnules of a frond at a post-embryonal stage, and that they are more numerous at the marginal regions than in the middle of a pinnule. When a plant has grown to its full size they occur in comparatively less numbers in the pinnules at the transitional region. The following table gives the manner of distribution. The figures show the number of glands in a square $\mathrm{mm}$.:- 
Number of Glands in a Pinnule at the Transitional Region.

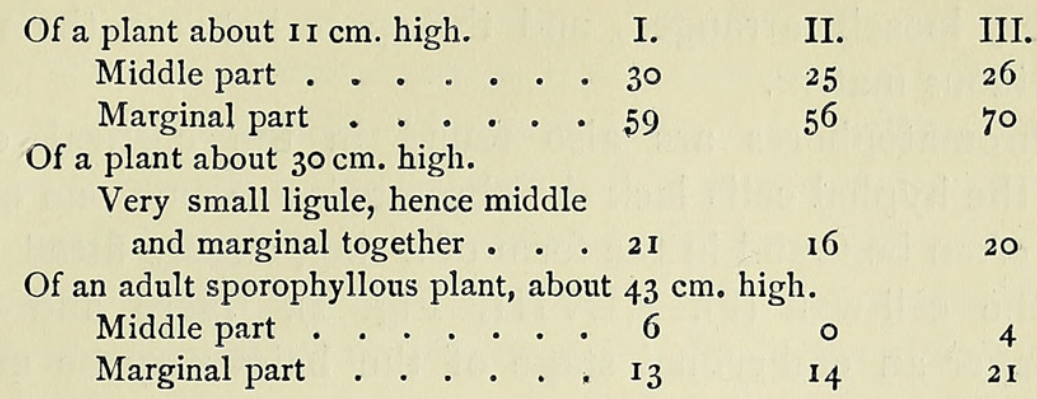

Number of Glands in Young and Old Pinnules of a Sporophyllous Plant about 43 CM. High.

\begin{tabular}{lcccccc} 
& \multicolumn{3}{c}{ Young Pinnule. } & \multicolumn{3}{c}{ Old Pinnule. } \\
Middle Part & I. & II. & III. & I. & II. & III. \\
Marginal part & 20 & II & 7 & IO & 7 & 5 \\
& & I6 & 2 I & I3 & I9 & 27
\end{tabular}

These spots are narrow spaces, mostly circular in surface view, with a diameter varying from to to $15 \mu$. Some are elliptical or ovate, measuring IO-I $5 \mu$ in the minor axis and $20-40 \mu$ in the major axis. In the younger pinnules which are found near the transitional region of a frond they are much smaller, often not exceeding twice the size of an epidermal cell. Those found in the rachis, though rather rarely, are narrow and longitudinally stretched. Before going further, a brief description of the structure of a young part of the lamina of Undaria will be necessary, as nothing has ever been reported concerning the matter. There are many interesting points to be considered in the morphology of Undaria. Description in detail may undoubtedly contribute various new facts to the knowledge of Laminariaceae. But I have to confine myself in this paper to remarking on the points which directly concern the subject under consideration.

In the essential characters the structure of a young part of the lamina of Undaria is similar to that of the rest of Laminariaceae. ${ }^{1}$ The epidermal layers are built up of a single stratum of elliptical cells with the major axes perpendicular to the surface of the frond. The cortex is built up of parenchymatous cells disposed in one or several irregular layers. The cortical cells, which are directly in contact with the epidermal layer, are angulate-polygonal and closely fit on to the inner side of the epidermal layer. In the transitional region the epidermal cells are nearly isodiametric and have a similar appearance to the contiguous cortical cells (Pl. XLVIII, Fig. 8). Both are, however, easily distinguished one from the other by the contents and future mode of development (Fig. I2). The inner cortical cells vary in shape from spherical to elongated-elliptical, and are arranged loosely and irregularly. The medullary portion between the two strata of the cortical

I Cf. Wille : Bidrag til Algernes Physiologiske Anatomi. K. Svenska Vet. Akad. Handlingar 2I. No. 12. 1885. Rosenthal: Zur Kenntnis von Macrocystis und Thalassiophyllum, Flora, 1890, and other papers. 
tissue consists of separate hyphal cells, often ending in a cortical cell. They are very loosely arranged, and the space between them is filled up with a gelatinous matrix.

The chromatophores are also found in the cortical cells. Large numbers of the hyphal cells lack the chromoplasts; but one or two of the grains may often be found in the form of a ring, closely fitted to the inner surface of the cell-wall (Pl. XLVIII, Fig. 2). Here and there in the epidermal layer an embryonal stage of the hairs may be met with in a depressed circular area. In the well-grown sporophyllous fronds numerous hyaline corpuscles are found in the cortical cells. These corpuscles turn yellowish brown in the dried or formalin specimens.

To understand the relative position of a gland and the space above it, or supraglandular space as it may be called, it was found best to apply a special staining matter to the former. The glandular contents stain much deeper than the surrounding tissue in aniline blue or in haematoxylin. A part of a frond is dipped in either of the colouring materials for a few minutes. It is then washed thoroughly in a diluted acid alcohol. In the case of anilin blue almost all parts of the tissues except the glandular contents are decolorized; in haematoxylin, the glandular contents are stained a purplish colour and the nuclei of other cells a bluish violet, while the cell-walls remain almost unstained. When a piece thus treated is observed from the surface under a moderate power, the position of the space above a gland is satisfactorily recognized (Fig. 1).

In the earlier stages, each supraglandular space is situated just above the centre of the gland. But as the latter grows larger, the space also increases in size, elongating, at the same time, into an elliptical or linearoblong area. The longer axis is always parallel to the margin of the pinnule. In the elongated old glands, the supraglandular spaces are in many cases stretched in the direction following the glands and are situated above their middle or terminal point. It has been ascertained that the most elongated glands lie near the margins of the pinnules, in such a degree as often to join with an adjacent one. There is little doubt that the direction of the elongation of both the supraglandular spaces and the glands is a consequence of the growth of the pinnule.

As soon as a ligule has appeared at the transitional region, the formation of glands begins to take place in it. Numerous completed glands are already to be found mingled with younger ones, when a ligule has attained to the length of $\mathrm{I} \mathrm{cm}$. The table given above reveals at once that the glands are formed in large numbers in the pinnules of a young plant and that they become rarer in the adult pinnules, as the pinnules increase in area, with few additional glands. The present writer obtained the best results by the following method of treatment, among various others, in searching after the mode of development of the glands. 
A piece of frond fixed beforehand in the picric acid and preserved in a strong alcohol is imbedded in paraffin. The sections are stained first in aniline blue. They are treated with 70 per cent. and 90 per cent. alcohol successively until the colouring matter is washed out without any shade of blue in the tissue except in the glands. The sections are then stained in fuchsin, then sealed in Canada balsam after the usual process. The glands are now stained a deep violet and the other parts of the tissue a beautiful red. Delafield's haematoxylin also answers well. In it the glands are stained a deep purple, while the remaining parts take a bluish violet colour. The former method of staining gives a sharper contrast of colours, while the latter is better for the purpose of studying the plasmic contents of the tissues.

The glands have their origin in the cortical cells which are situated directly beneath the epidermal layer (Fig. 8). These cortical cells are so closely in contact with the overlying cells as to give a distromatic appearance to the epidermal layer. That the epidermal layer is never distromatic may be proved by comparing the cell-contents and the future development of both layers. As the first step of the gland formation, one of the cortical cells begins to swell up gradually, undoubtedly gaining its nourishment from its contiguous cells. As the glandular cell swells up, the epidermal cell situated just above it is gradually compressed upwards. The surface of the latter retains its former position in the same level with the neighbouring ones. The consequence is the diminishing of the cell-cavity. The cell-contents are dissipated by degrees, but the nucleus is limited to the narrow space now allowed for it (Fig. IO). The glandular contents are at this stage already differentiated, so as to assume a deeper staining than the others, and change into a hyaline plastic mass filling up the whole cavity of the swollen cell. The epidermal cell is finally flattened into a thick hyaline membrane, roofing over the gland. Hence it may be clearly understood that there is not any actual perforation upon a gland. Thus the primary supraglandular space is formed.

In the surface view of the epidermal layer we often find two or three contiguous cells in course of degeneration (Fig. 4). This may be interpreted in two ways. In the first case two or more cells are sharing in the formation of one supraglandular space, as shown in Fig. 9. In the second, two or more supraglandular spaces may be in course of formation, each with a gland below, as shown in Fig. I0. Practically, however, the former case seems to be more frequent than the latter. As an abnormal case it was found that the epidermal cell upon the embryonal glandular cell did not degenerate, but both fused together into a long cylindrical cell (Fig. I3). In a rare case three cells, the one epidermal and the others cortical, serially disposed perpendicularly to the surface of the frond, have swollen up as shown in Fig. I4. The innermost cell stained deepest, in 
the same degree as the other glandular cells, and the epidermal one hardly at all. I can only explain this arrangement of cells as an aberrant mode of formation of the gland. The two septa would probably decompose subsequently, resulting in an oblong glandular cell.

After the epidermal cell has completely atrophied and the supraglandular space has been first formed, the glandular cell ceases to grow towards the surface of the lamina. The addition to the size of the gland takes place mainly at the inner end of the cell (Fig. II). As the glandular cell increases in size, the cells around it are evidently pressed aside. But the epidermal cells seem to have been disturbed in a very little degree by the pressure, and their division and growth continue as the lamina extends. This will be treated further in connexion with the growth of the supraglandular spaces.

The glands add to their size at their inner ends, displacing the loosely arranged surrounding cells. Hence their shape, which was first ovate or pyriform, with the sharper end towards the surface of the lamina, becomes roundish-pyramidal or compressed-conical. In the next stage, most of them, if not all, grow horizontally, elongating in the direction of the longer axis of the pinnule. In the cross-section of the lamina such glands appear as flattened cones with the apices protruding towards the supraglandular spaces. But in the surface view it is clearly to be seen that the glands have their largest diameter at the point below the supraglandular space, and that the horizontal elongations are outgrowths from such principal part (Fig. I).

It was not ascertained whether any neighbouring cortical or hyphal cell has or has not amalgamated with the glandular cell during its growth. Judging from the arrangement of the cortical and hyphal cells around a completed glandular cell, I am inclined to believe that none has fused to add to its size. The direction of the outgrowth is due to the fact that the hyphal cells are largely running parallel to the margin of the pinnule-the direction of the growth of the pinnule-and thus it has fewest obstacles to its elongation in that direction.

As the primary epidermal cells in the transitional regions are cubical, the supraglandular spaces, when they are first formed by the normal process above referred to, are naturally square in surface view. They are hardly larger than the size of an epidermal cell. As the pinnule grows larger the spaces are also extended in area, retaining their former shape or elongating into a rectangular form. This is due to the fact that an epidermal cell divides into four successively by partition walls perpendicular to one another. In the fresh specimens, as well as in those fixed in picric acid, this mode of cell multiplication is not clearly seen, for the cells are closely compressed together. But when the material is fixed in the sublimate solution, the boundaries between the groups of the cells are vividly shown by the hyaline middle lamella. Each group consists of four cells cruciately 
arranged. It may be geometrically proved that the primary supraglandular space extends four times in area as each surrounding cell divides into two ; and that, when the cells on two opposite sides divide quicker than those in the other two, the results will be rectangular spaces. This is practically proved in the early stages of the formation of the spaces (Figs. 5, 6).

As a frond grows further, the epidermal cells increase in number and size. As a fact, the cells surrounding a space multiply less quickly than those in a more remote position. The result is, as the geometrical principle may well prove, the radial arrangement of the cells with the space as the centre. Eventually the space gradually approaches to a round or elliptical area as it widens. Moreover, the cells bordering a space tend to elongate towards its centre as the mutual compression leaves that side entirely free. As a consequence, the cells surrounding a supraglandular space apparently converge towards its centre, as has been described by Okamura (Fig. 7).

The contents of a primitive gland are a comparatively large nucleus and many colourless hyaline grains enclosed in a thin coating. As the gland grows larger the grains increase in number and remind one of a potato cell full of starch grains (Fig. 2). In some glands, during observation under the microscope, the contents have suddenly turned into a homogeneous mass, resembling, in a manner, the action of a strong potash solution upon the starch grains in a potato cell. The mass contained in the gland then made its way through the supraglandular space, changing into a mucilaginous matter, undoubtedly by the turgor-pressure of the gland. The semi-fluid which is ejected from the surface dissolves away by degrees in the surrounding medium. I was not able to detect any sort of opening in the external covering of the gland. But judging by the speed of the emission, the roofing membrane over the gland must have burst open to form a passage at that moment.

At the moment when the glandular contents have been freed from the gland, the mass forms a globular body upon the supraglandular space and rests there for a considerable time. This is not recognizable, even under a high power of the microscope, before treating with the colouring matter, as the refracting power of the mass is nearly equal to that of water. Staining by aniline blue, however, shows the mass very clearly; at the same time the mass remaining in the gland assumes the same colour. Hence in such cases, one globular body is seen on each side of an epidermal layer, constricted at the newly opened supraglandular passage. It is very interesting to note that the aniline blue can do nothing to the glandular contents before it has diffused into the homogeneous mass. In the microtome sections the glandular contents, in both young and old, are seen as a reticulated or areolar mass adhering to the inner surface of the wall, and there is hardly any difference in the degree of staining.

Okamura suspected that the 'bag' might be a sort of excretory organ. 
It is not very clear to me how he came to think of finding an excretory organ in an alga. It is now established that the mass contained in the ' hyaline bag' is not a coloured solid substance while in the living state, but a colourless, plastic semi-fluid. The chemical properties, however, of this mass are not yet satisfactorily known to me. But I have ample reason to believe that the problematic cell is a gland secreting a mucilaginous substance.

It is rather doubtful to me whether the mucilaginous substance actually flows out in nature through the supraglandular space in the manner just alluded to above. What I have observed might have been due to an unusual turgescent state of the glandular cells during the preparation. The thick membrane roofing over the gland seems to be strong enough to hinder the free emission of the substance. But judging from the fact that the compressed matter in the gland seeks its way through the thick membrane and not by bursting the thin coating, it is more legitimate to believe that the weakest part of the membrane is at the roof, and that the contents pass out slowly by osmotic action through this part.

The fronds of Undaria, Hirome, and Undariopsis have been described as lacking the mucilage canals. Yet the plants belonging to these genera are highly gelatinous to the touch while in the fresh state. That it is due to the mucilage thinly coating the surface of the frond may be proved by the reaction of an aniline blue solution. A fresh frond is dipped in toto in the solution: the mucilage is stained, and at the same time coagulates into a flaky matter. This coagulated matter may be easily brushed away, leaving the surface of the frond highly resistant to friction.

So far as researches on the mucilage ducts of the other Laminariaceous plants extend, there is no positive proof that the ducts have free openings in the surface of the frond. The canals may terminate at the epidermal layer, but are always closed at the end by a single layer of cells. We are led to believe that the mucilage is squeezed out through this layer. This suggests the probability of the above hypothesis relating to the gland under consideration.

It was remarked above that the glandular contents stain very well in the fresh material after the granular structure has disappeared. This may lead us to suppose that the contents had changed their chemical properties before and after the transformation. It must be borne in mind, however, that aniline blue stains plasmolyzed cell-contents much deeper than those in a turgescent condition. This is true for all living cells of Algae, so far as my experience extends. The exceptions are met with in special absorption-organs such as the hairs of the Phaeophyceae. So also in many phanerogamic cells. The glands whose contents have changed into a hyaline homogeneous mass might lose some of their contents through the supraglandular coating. The plasmic membrane coating the inner 
surface of the glandular cell-wall will have been relaxed and pressure released. In other words, the glandular cell must have been plasmolyzed unless it had a thin dilatable cell-wall. The difference in the degree of staining might have been due to the degree of turgescence rather than the chemical properties. But this is merely my supposition and needs further proof.

\section{SUMMARY.}

I. Undaria has numerous glandular cells scattered in the lamina.

2. As a rule, each glandular cell originates from a single cortical cell which is in contact with the epidermal layer.

3. The epidermal cell upon a glandular cell degenerates as the latter develops, leaving a membranous coating over the gland. substance.

4. The function of the gland is possibly to secrete a mucilaginous

5. The glands found in the lamina of Hirome and Undariopsis will probably prove to be similar to those of Undaria in their mode of development and function.

\section{EXPLANATION OF PLATE XLVIII.}

\section{Illustrating Prof. Yendo's paper on the mucilage glands of Undaria.}

Fig. I. Surface view of a portion of a pinnule stained in toto with aniline blue. The left side, shown in thick outline, indicates the margin; the lower end is toward the rachis. $a, b, c$, various stages of development of the cryptostomata. $\times 54$.

Fig. 2. Cross-section of a pinnule, showing a gland with granular contents; from fresh material. $\times 450$.

Fig. 3. Surface view of a supraglandular space; from fresh material. $\times 450$.

Fig. 4. The same, with the three contiguous cells in course of degeneration. $\times 450$.

Figs. 5-7. Surface view of the supraglandular spaces, showing the stages of development. $\times 250$.

Fig. 8. Cross-section of a frond with two young glands. $\times 1050$.

Fig. 9. A gland at a stage a little more advanced. Two epidermal cells above the same gland. $\times$ I050.

Fig. Iо. Two glands side by side. $\times$ 1050.

Fig. II. A glandular cell nearly completed; typical form. $\times 1050$.

Fig. I2. Cross-section of one of the youngest pinnules of a sporophyllous frond, preserved in formalin. $\times 45^{\circ}$.

Fig. I3. Various stages of development of the glands. In the middle one the epidermal cell seems to have fused with the glandular cell. $\times 10_{50}$

Fig. I4. An abnormal gland. $\times 1050$. 


\section{ERRATUM}

Page 616, top line, for separate read septate

Annals of Botany

No. XCII. 
Annats of Botany

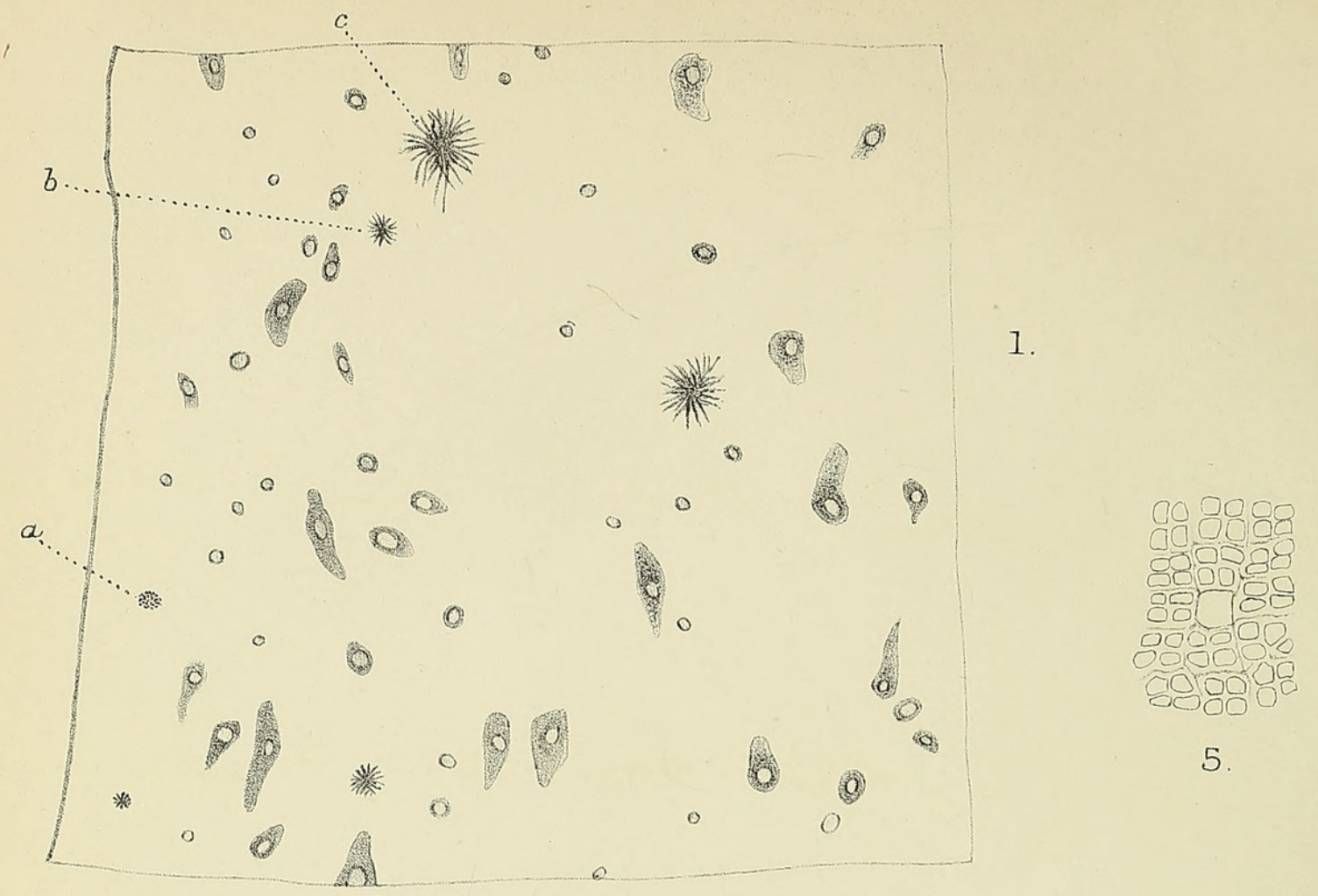

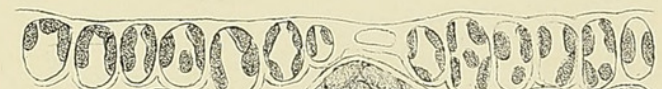
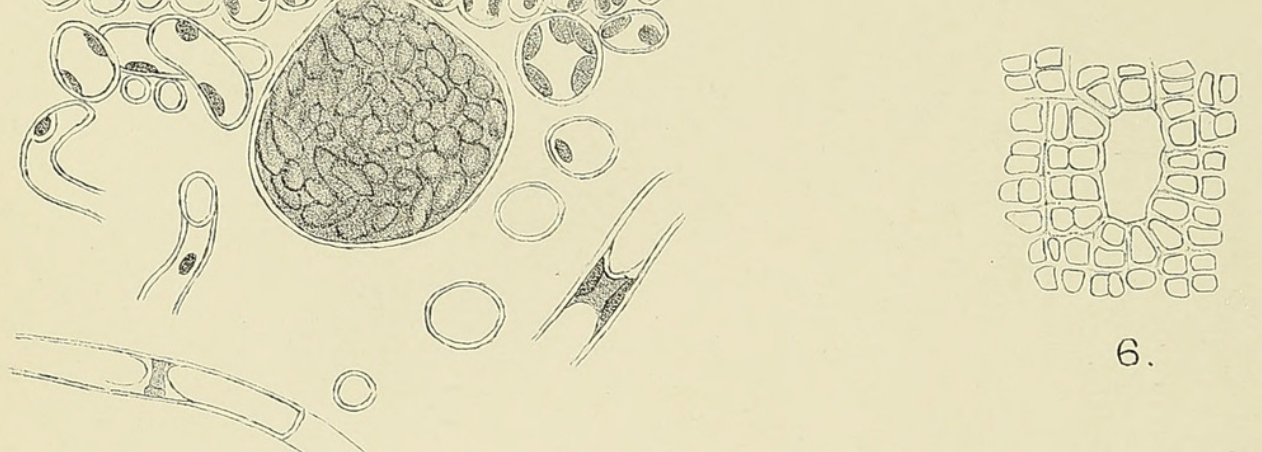

6.

2.
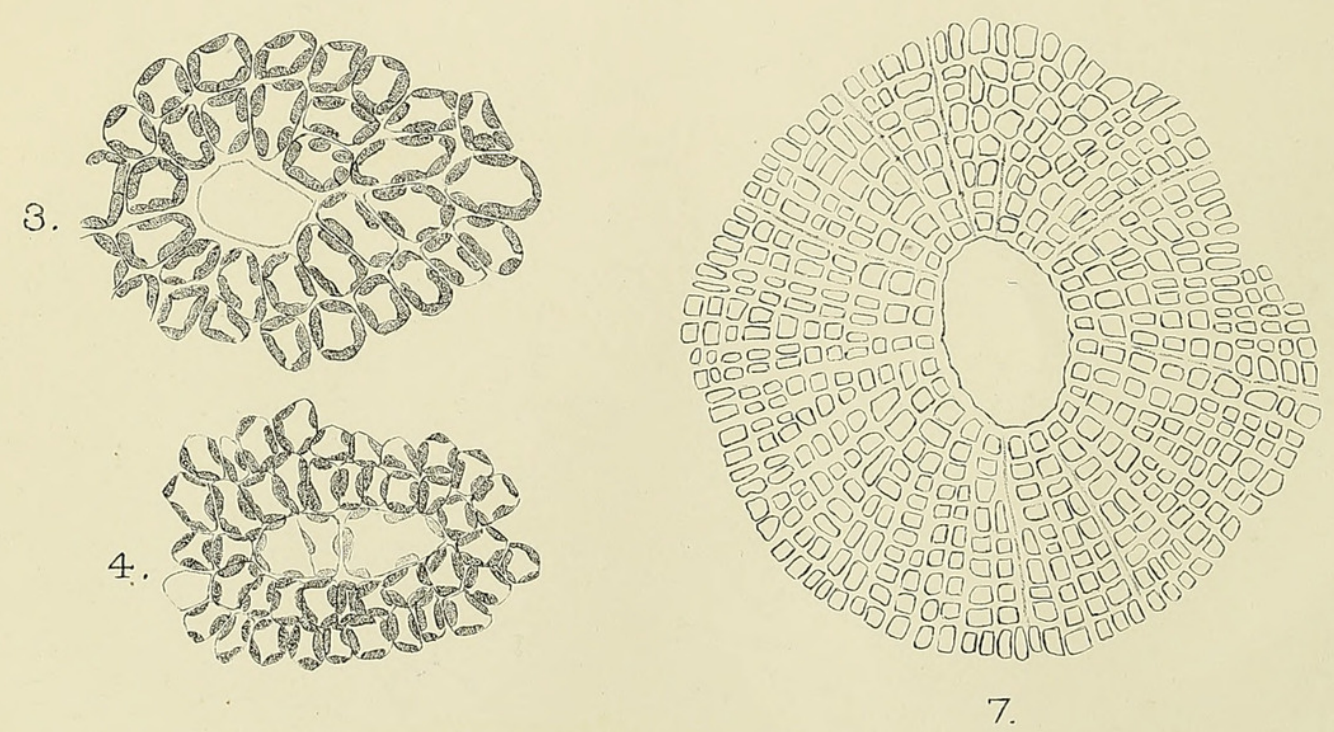

KYendo del 


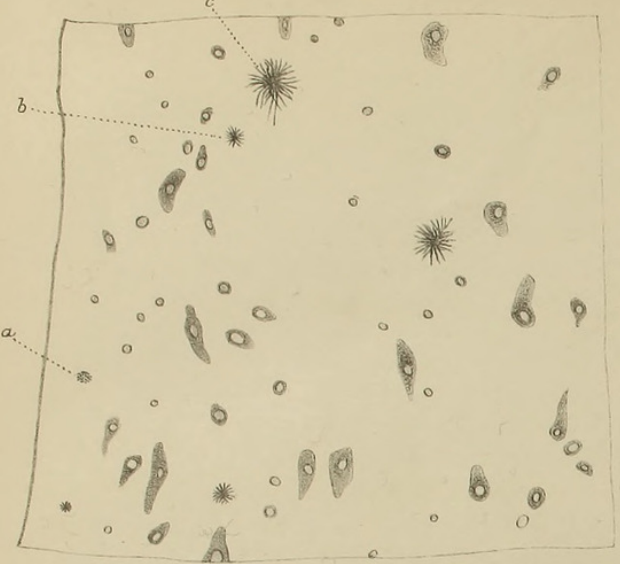

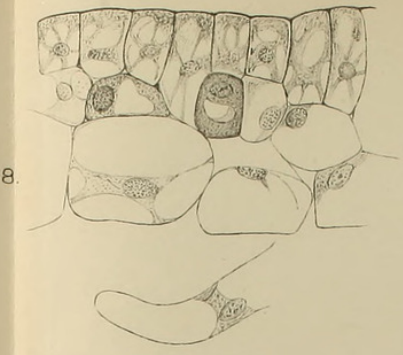
00(4)

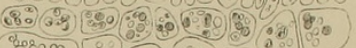

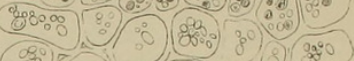

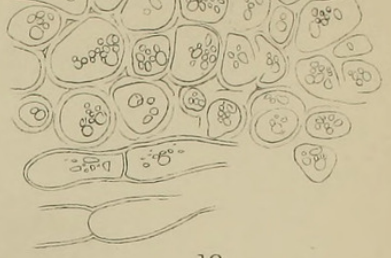

12.

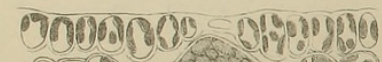
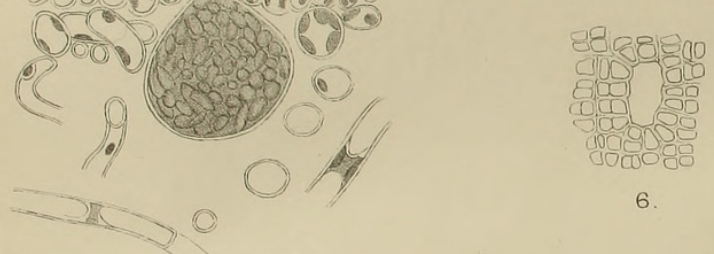

5.
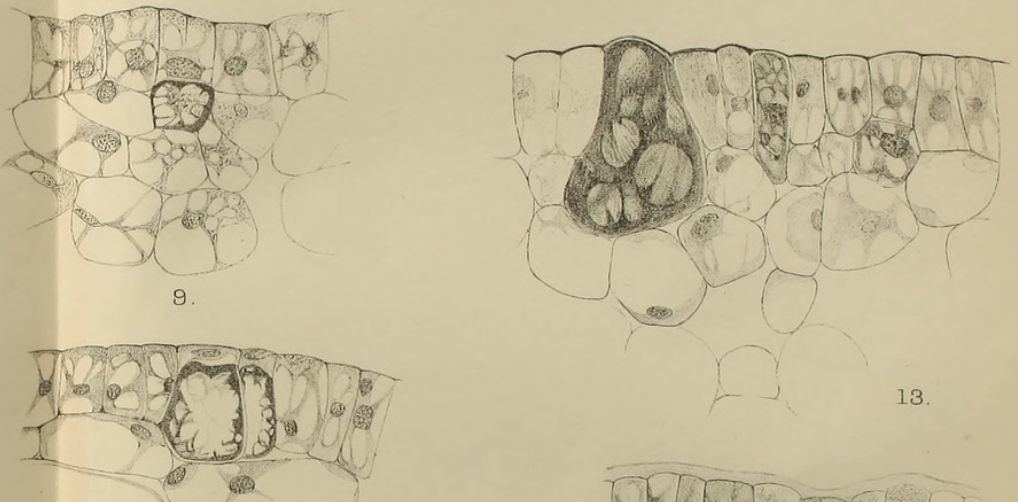

30
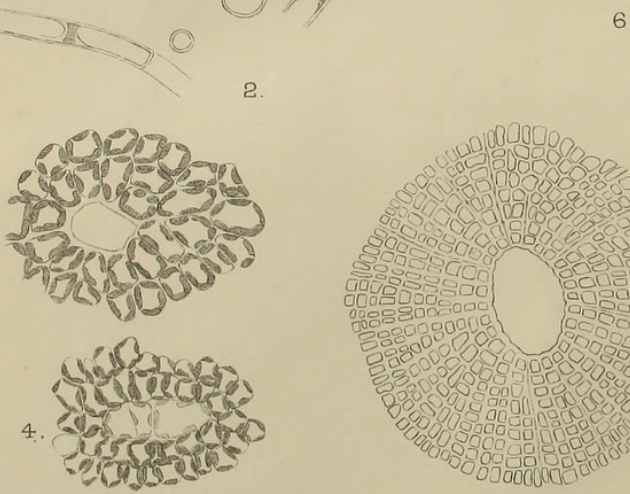

7.

. 


\section{$2 \mathrm{BHL}$ Biodiversity Heritage Library}

Yendo, Kichisaburo. 1909. "On the mucilage glands of Undaria." Annals of botany 23, 613-621. https://doi.org/10.1093/oxfordjournals.aob.a089243.

View This Item Online: https://www.biodiversitylibrary.org/item/236540

DOI: https://doi.org/10.1093/oxfordjournals.aob.a089243

Permalink: https://www.biodiversitylibrary.org/partpdf/318978

\section{Holding Institution}

Smithsonian Libraries

\section{Sponsored by}

Biodiversity Heritage Library

\section{Copyright \& Reuse}

Copyright Status: Not in copyright. The BHL knows of no copyright restrictions on this item.

This document was created from content at the Biodiversity Heritage Library, the world's largest open access digital library for biodiversity literature and archives. Visit BHL at https://www.biodiversitylibrary.org. 